\title{
MIGRATION FROM THE MIDDLE EAST TO THE EUROPEAN UNION. A COMPLEX PHENOMENON
}

\author{
Ahmet DAȘTAN \\ National University of Political Studies and Public Administration \\ Bucharest/Romania \\ ahmet.dastan@lumina.ro
}

\begin{abstract}
This article aims at reflecting the complexity of factors that determine the migratory flux that connects two of the most important geopolitical actors of today's world stage: the European Union and the countries of the Middle East. Through an analysis of relevant academic sources and statistical data provided by institutions and organizations like the World Bank, Eurostat or the U.S. Department of State, a detailed analysis of the phenomenon of immigration from the Middle East to the EU territory will be made and several conclusions regarding the main factors that determine this phenomenon will be identified.

The first part of the article consists of a short analysis of the key concepts that form the basis of the more complex argumentation regarding the main factors that determine directly or indirectly the ample phenomenon of migration from the Middle East to the European Union and that will be made in the second part of the paper. These key concepts refer to the geographic boundaries of the two regions that are in the center of the analysis (the European Union and the Middle East) and the geopolitical context that characterize the situation of the two entities. After this theoretical foundation is set, a more detailed analysis of the migratory flux to the European Union in general and of the migratory flux from the Middle East region in particular is made. The results of the analysis show that there is a complex of determinant factors that explain the migration
\end{abstract}


flows between the two regions, but only a couple of factors can be considered as being essential: the continuous state of armed conflicts in the Middle East and the differences in economic development between the countries that form the Middle East region and the EU Member States.

\section{Keywords:}

The European Union; the Middle East; migration

\section{INTRODUCTION}

Although migration is not a new phenomenon, the amplitude of migratory tendencies in the past century reflects that migration as a human activity has taken on a new form under the influence of modern developments like globalization, the opening of borders for foreign workforce, the internationalization of the educational process or the opportunities provided by migrants through international agreements (e.g. the UN Global Migration Pact of 2016).

The particular migration flow between the Middle East and the European Union has not been an exception to these tendencies, the amplitude of this flow being the highest in all recorded history (Dastan, 2019). Although the migratory waves between the two regions can be explained by the same elements that have determined the intensification of migratory tendencies in the past decades (e.g., globalization, internationalization etc.), the Middle East - European Union migration axis has its own particularities determined by specific historical, geographical, social, economic or geopolitical factors. The multitude of factors that indirectly determine the migration between the Middle East and the European Union give complexity to this phenomenon and indirectly determine the need of studying the recent migration tendencies through the specific tools of academic research.

Starting from these premises, we will analyse in this article the main elements that characterize the complexity of migration to the Middle East to the European Union, with emphasis on the analysis of the migratory influxes to the EU from 
different regions of the world, the analysis of the particular case of the Middle East as a source of migration to EU Member States and the analysis of the sociopolitical context that determine the particularities of Middle East - EU migration flow.

\section{KEY CONCEPTS}

In order to correctly evaluate the migration fluxes between the Middle East and the European Union, it is necessary to clearly define the two regions from a geographical and geopolitical perspective. The definition is easier to provide in the case of the EU, a region that is clearly identified in the official documents of this supranational construction founded by six states in the 1950s and enlarged through several waves that took place in the last decades of the $20^{\text {th }}$ century or the first two decades of the $21^{\text {st }}$ century (the last three countries that have acceded to the EU are Romania and Bulgaria in 2007 and Croatia in 2013).

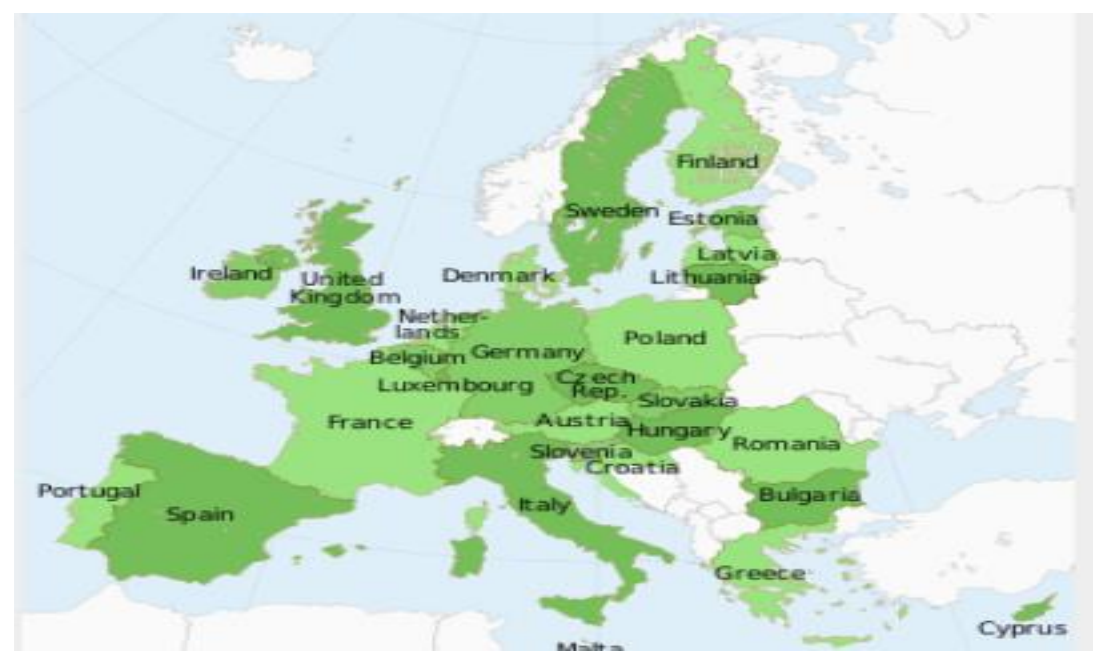

Figure 1. Map of EU Member States

Source: Schengen Visa Info. 2019. "The European Union and countries in the EU." Accessed November 12, 2019. https://www. schengenvisainfo.com/eu-countries/. 
The process of EU enlargement is likely not to end in the near future, since one of the European Union's priorities is that of intensifying the negotiations with candidate states from the Western Balkans (e.g. Serbia, Montenegro, North Macedonia or Albania) and other countries that are geographically placed in the Eastern region of Europe (e.g. Turkey, Kosovo or Bosnia and Herzegovina) (Adamczyk, 2018).

Because the Member States of the European Union are clearly identified in treaties and other official documents, the borders of this transnational organization are easily identifiable on the world map. This is not the case with the Middle East region, whose boundaries have been defined differently by scholars throughout history. Examples in this respect are the approach of Yousef (2004), who drew the limits of the Middle East between the South-Western Asia and North-West Africa, Binder (1958), who argued that all states that were part of the Ottoman Empire have to be included in this region, or Noble (1991), who stressed the importance of drawing the boundaries of the Middle East region by taking into consideration the relations established between Arab countries and the mechanisms of interaction between strong states, like Israel, Turkey and Iran, on one hand, and the weaker states, on the other hand. In order to analyse the migration flow from the Middle East to the European Union, this article will refer to the boundaries of the Middle East recognized by most scholars, who include in this region not only the states that are geographically placed in the Arabic Peninsula, but also states that comprise the Northern African region and states that border the Arabic Peninsula from the North (Faucett, 2016). 


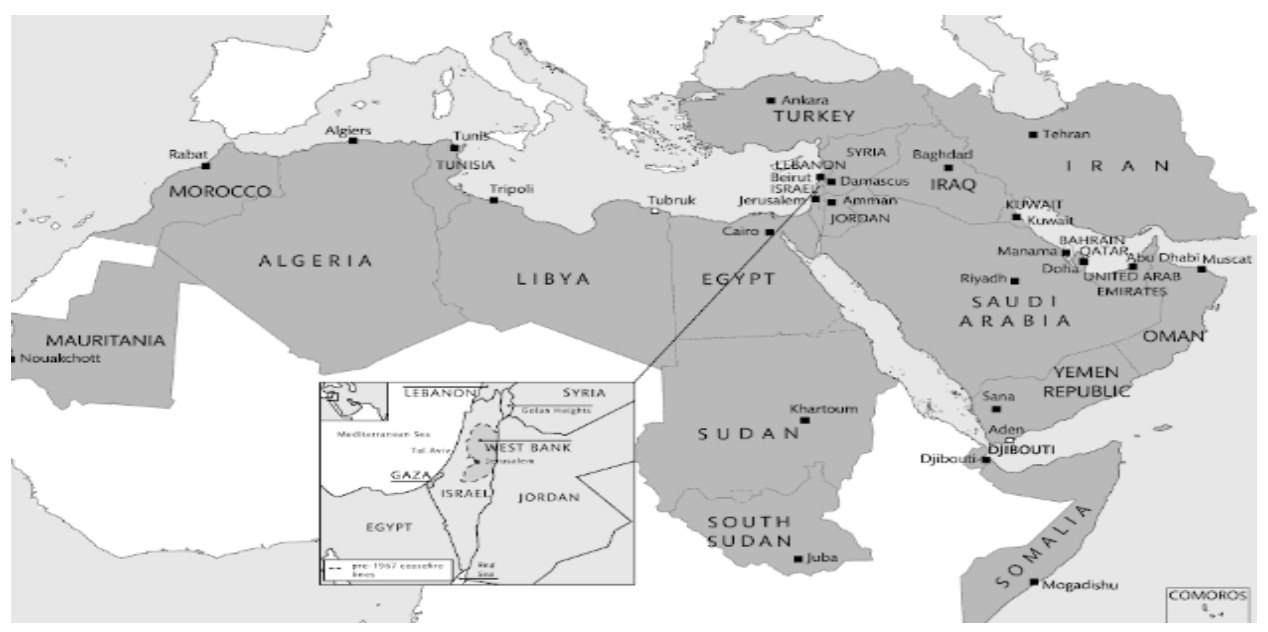

Figure 2. Map of the Middle East

Source: Faucett, Louise. 2016. "Introduction: The Middle East and International Relations." In International Relations of the Middle East, edited by Louise Faucett, $4^{\text {th }}$ edition. Oxford: Oxford University Press.

In order to make a well-grounded analysis of the migration flow from the Middle East to the European Union, it is needed not only to correctly make a geographical delimitation of the two territories, but also to understand the geopolitical situation that characterizes both regions. In the case of the EU, the geopolitical context is far simpler than the geopolitical context of the Middle East because the relations between the Member States of the European Union are clearly defined by treaties and other official documents. On the other hand, the Middle East is a territory placed between three continents, a geographical space that represents the origin of three of the world's most important religions (Judaism, Islam and Christianity) (Schimmel, 1992), a land with a soil rich in natural resources and a geopolitical arena formed of many ethnic minorities (Nisan 2012). All these elements create an image of a territory of conflicting interests that hinder the development of the Middle East from at least two perspectives. The first perspective is derived from the fact that conflicting interests prevent the states in cooperating for achieving their economic potential, while the second perspective is derived from the fact that conflicting interests 
often escalate and lead to tensions and even wars. Both perspectives ultimately generate the same effects, represented by unrest, frictions, social imbalances, all these representing factors that determine people to migrate and seek a better life on the territory of the European Union.

\section{THE MIGRATORY FLUX TO THE EUROPEAN UNION}

One of the most important characteristics of the migratory flux to the European Union is determined by the fact that not all Member States are equally targeted by migrants. Western countries, which are more developed from an economic point of view and have democratic institutions that have been functioning for a longer period of time, are preferred by migrants in the detriment of Eastern countries, where the wealth of the average citizen is lower and where democracy is still in its infancy after many decades of communism.

Table no. 1. Comparison between the number of immigrants in several Western and Eastern European countries in 2016

\begin{tabular}{|c|c|}
\hline Country & Number of immigrants (thousand immigrants) \\
\hline Germany & 507 \\
\hline Great Britain & 285.4 \\
\hline Spain & 235.8 \\
\hline Italy & 200.2 \\
\hline France & 158.2 \\
\hline Lithuania & 5.2 \\
\hline Estonia & 4.2 \\
\hline Croatia & 4 \\
\hline Latvia & 2.9 \\
\hline Slovakia & 0.6 \\
\hline
\end{tabular}

Source: Eurostat. 2017. "Immigration by citizenship." Accessed October 16, 2018.

https://ec.europa.eu/eurostat/statistics-

explained/index.php?title=File:Immigration_by_citizenship,_2016.png. 
The data in the table above shows that Western countries like Germany, Great Britain, Spain, Italy or France are more attractive to immigrants than Eastern countries like Lithuania, Estonia, Croatia, Latvia or Slovakia. The latter are less attractive not only because they have less developed economies, but also because the democratic values of protecting the human rights in general and the rights of the migrants in particular have not yet been tested in the same manner as they have been tested in Occidental democracies with a long history of migrants' assimilation.

The migration flux to the European Union is characterized not only by imbalances in relation to the destination countries, but also by imbalances in relation to the sources of migration. Taking as a landmark the year 2014, statistics show that almost half of the immigrants came from a single country (Syria) and that only four other countries have represented the source of migration to the EU for over 30,000 migrants (Afghanistan, Kosovo, Eritrea and Serbia).

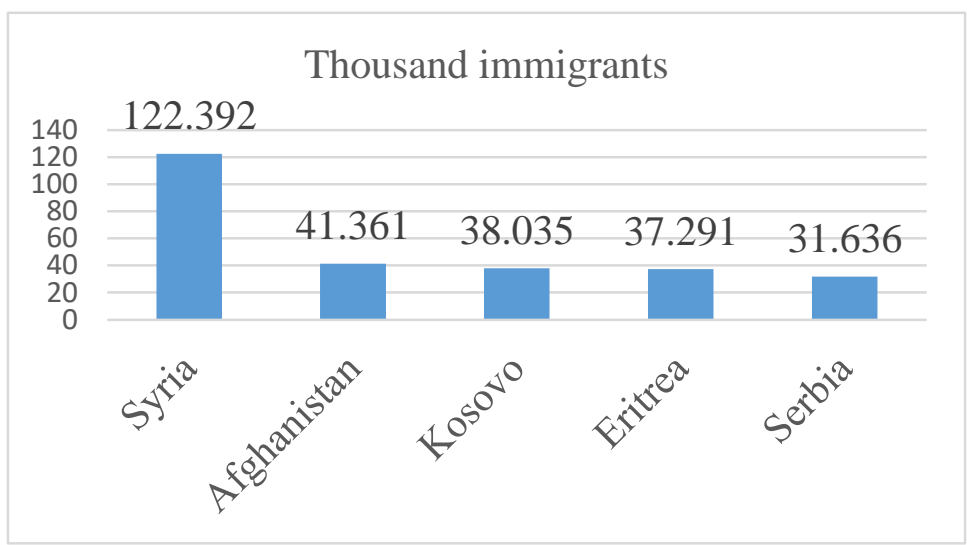

Figure 3. Main sources of immigration to the European Union in 2014 Source: European Commisssion. 2015. "Legal Migration in the EU. From Stop-Gap Solutions to a Future-Proof Policy." EPSC Strategic Notes, no. 2. Accessed October 15, 2018. https://ec.europa.eu/epsc/sites/epsc/files/strategic_note_issue_2.pdf. 
Other important sources of migration to one of the Member States of the European Union are Pakistan (approximately 22,000 immigrants in 2014), Iraq (approximately 22,000 immigrants in 2014), Nigeria (approximately 20,000 immigrants in 2014) and Russia (approximately 20,000 immigrants in 2014). These data, combined with the ones presented in the figure above, show that the European Union represents a target not only for immigrants who come from countries that are close from a geographical perspective (e.g. European countries like Serbia, Kosovo or Russia), but also for immigrants who come from distant countries like the ones from Asia (e.g. Syria, Afghanistan or Iraq) or Africa (e.g. Nigeria or Eritrea). As a result, it can be concluded that the general flux of migration to the European Union is not characterized by geographic barriers, the motivation of the immigrants to reach one of the EU Member States being oftentimes more powerful than the inherent difficulties that migrants have to overcome if their country of origin is far away from a geographical perspective.

\section{THE MIDDLE EAST AS A SOURCE OF MIGRATION TO THE EUROPEAN UNION}

\subsection{Socio-political, historical and cultural context}

The context that may explain the migratory flux from the Middle East to the European Union is determined by several elements: the demographic structure of Middle East countries, the economic and political situation in these states, the development of radical movements and the historical evolution of relations between countries from the two regions.

The first of these elements, the demographic structure, shows that the Middle East region is comprised of several large states, with a population of over 80 million inhabitants, but also of very small states, with a population of less than 5 million inhabitants. 


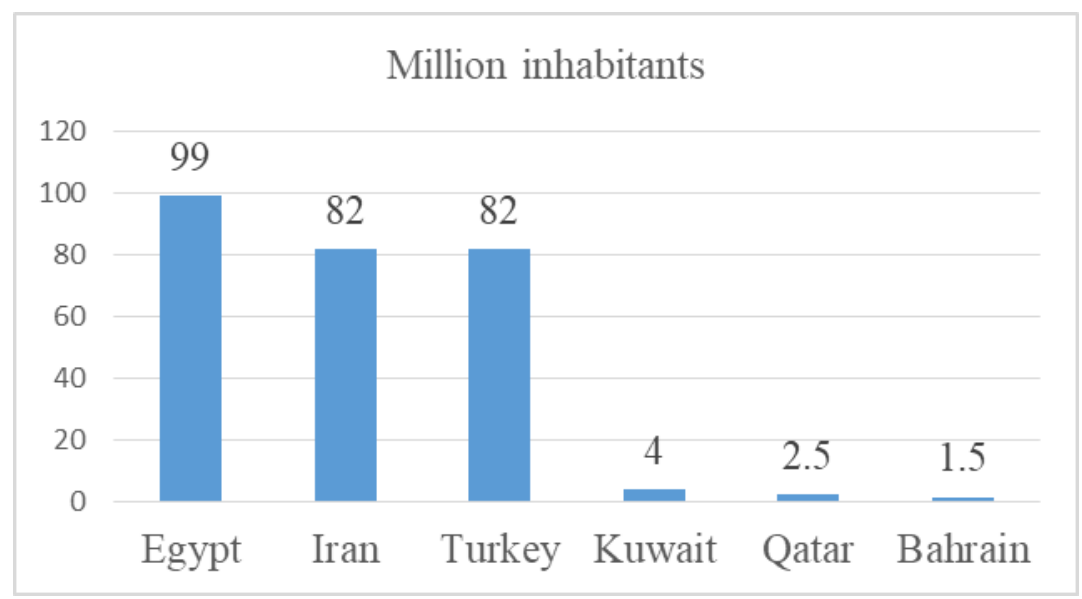

Figure 4. The states with the highest and lowest number of inhabitants in the Middle East region

Source: World Population Review. 2018. "2018 World Population by Country." Accessed October 17, 2018. http://world population review.com/.

These data show that the migration flux from the Middle East to the European Union is more likely to be comprised of people that come from countries with a large number of inhabitants (e.g. Egypt, Iran or Turkey) that of people originating from small states like Kuwait, Qatar or Bahrain.

It is more likely that immigrants originate from large countries, but, at the same time, it is more likely that immigrants originate from states that are less developed from an economical perspective. As a result, another important element that contributes to the development of a context for the migratory flux between the Middle East and the European Union is represented by the poor economic situation of the countries that are placed geographically in the Arabic Peninsula or Northern Africa. According to the official statistics provided by the World Bank, most of the states of the Middle East have a difficult economic situation that creates the premises for a large flux of emigration. 


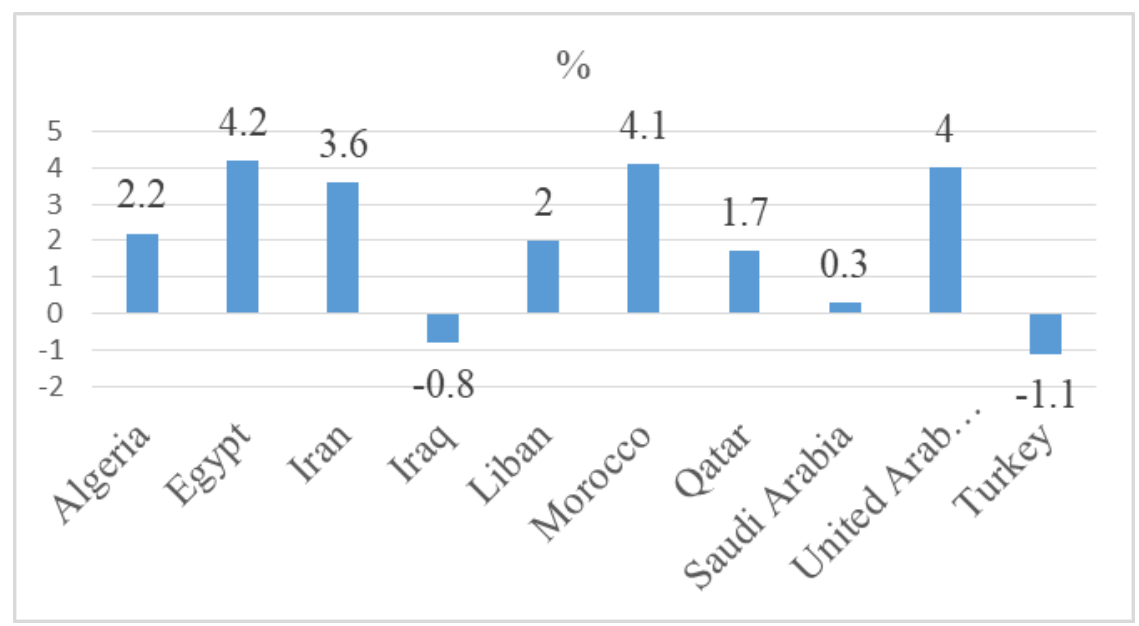

Figure 5. Gross domestic product variation in 2017 compared to 2016 Source: World Bank. 2018. "Global Economic Prospects 2018: Middle East E North Africa.". Accessed October 19, 2018. https://www.worldbank.org/en/region/mena/publication/gep-2018.

The statistical data in figure above shows that the most favorable situation is that of countries that have a slow economic growth, of less than 5\% (e.g. Egypt, Morocco, United Arab Emirates or Iran), but there are states in the Middle East region where the growth is almost non-existent (e.g. Saudi Arabia) or where the economy is in recession (e.g. Turkey or Iraq).

As a result, the economic situation may be considered as being an important element that characterizes the context of migration from the Middle East to the European Union, but this context cannot be fully understood if we do not take into consideration the political factor. From a political perspective, it is important to mention the fact that the Middle East region was under the influence of a unique power represented by the Ottoman Empire prior to World War I (Owen, 2013). After the fall of this major political power in the region, the states comprising the Middle East region have followed different political paths. For example, the Nasser Regime in Egypt has abolished the political parties in 1953 and has founded new political parties, a new system being implemented by 
the Sadat regime in the 1970, when three new political parties were founded (Waterbury, 2014). Another example is that of Syria, where the Asad regime has implemented in the 1970s a centralized system based on systematic control from different state institutions (Owen, 2013). A third example is that of countries like Libya, Yemen or Qatar where 'instability' is the main adjective that could characterize the political system. In Libya, for example, there have been many crises of electricity, gas or water, in Yemen there is a continuous armed conflict between the Houthi rebels and the government, while Qatar is accused of supporting radical organizations like Hamas (Black, 2014).

The development of radical movements may be considered a problem not only in Qatar, but in the Middle East region as a whole and represents, along with the generalized political instability, an important factor that may explain the large migratory flux from this region to the European Union. The complexity of the problem represented by the development of radical movements in the Middle East region is reflected by a report of the U.S. Department of State, an institution that has identified numerous terrorist organizations in countries like Afghanistan (Al-Qaeda), Egypt (Gama'a al-Islamiyya), Lebanon (Hezbollah), Iraq (Kudish Batalions of Al-Qaeda, Jaysh Rijal al-Tariq al Naqshabandi), the Palestinian Territories (Al-Aqsa, Palestinian Islam Army), Tunisia (Ansar alShari'a) or Algeria (Al-Qaeda in Maghrebian Islam) (U.S. Department of State, 2017).

Many of these organizations have only developed in the past decades and could be considered as an important factor that determines recent emigration, but the larger migratory flux between the Middle East and the countries on the European territory cannot be fully explained if we do not take into consideration the more complex relations that have developed in a period of over 1,000 years between the two regions. The first intense interactions between the Middle East and the European territory were the ones that emerged in the period between the $8^{\text {th }}$ and the $15^{\text {th }}$ century, when vast regions in Spain and Sicily were under the Islamic domination, a period characterized by numerous conflicts, the most important ones being the crusades in 1095 and 1291 and the Reconquista of the second half of the 1600s (O'Callaghan, 2013). This period of armed conflicts was followed by several centuries of fructuous cultural collaboration between the 
two regions and, at the same time, by a deepening of the ridge between Islam and Christianity (Hashas, 2018). This phenomenon has determined many EU countries and the EU as a whole to involve more and more actively in the Middle East region through partnerships developed with the United States of America and countries in the region like Lebanon, Syria, Turkey, Algeria, Egypt, Morocco or Israel (Lazar, 2005). These alternative periods of conflicts and close cooperation through partnerships or cultural exchanges between Europe and the Middle East show that there has been a continuous flux of ideas and capital between these geographical spaces in the past centuries and that migration represents only a specific manifestation of the historical interactions between the two regions.

\subsection{Causes of migration}

The contextual analysis made in the previous section of the article has shown that there is a complex of factors that could explain the phenomenon of migration between the Middle East and the European Union, but there are two main elements that determine the immigrants to leave their countries of origins and settle in one of the Member States of the EU: the military conflicts and the economic determinants.

The Middle East is probably one of the regions of the world with the most armed conflicts, the longest political tensions and the wars with the most estimated victims. According to the data of Totten, Bartrop and Jacobs (2008) and Gerner (2018), there has not been a day of peace in the Middle East in the past century, the conflicts with the highest number of estimated victims being the following: 


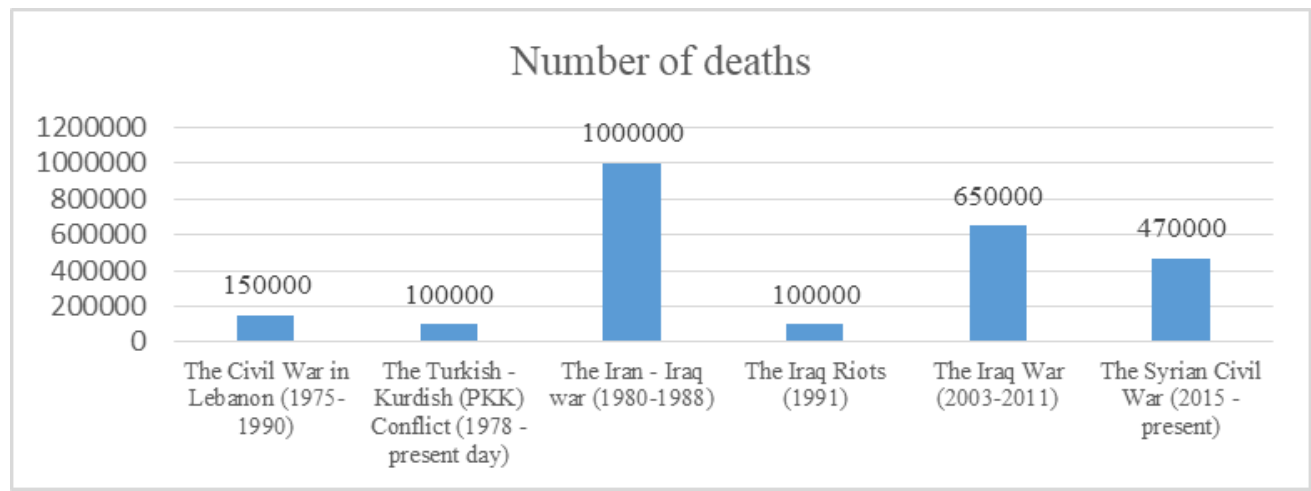

Figure 6. Number of victims in different Middle East conflicts

Source: Totten, Samuel, Paul Bartrop and Steven Jacobs. 2008. Dictionary of Genocide. Westport: Greenwood Publishing Group, 18-21 and Gerner, Deborah. 2018. One land, two peoples: The conflict over Palestine. Abingdon: Routlege, 48.

Each of these conflicts has indirectly determined a wave of migration from the Middle East to the European Union, the last major conflict that has generated a massive flux of immigration being the Syrian Civil War, which has inflicted a crisis at the level of the EU Member States (Romero, 2019).

The second important cause of migration is represented by the economic differences between the less developed countries in the Middle East and the advanced economies of the EU Member States. These differences are best reflected by a synthetic statistical indicator, the gross domestic product per capita.

Table no. 2. Gross domestic product/capita in several Middle East countries

\begin{tabular}{|c|c|}
\hline Country/Entity & Gross Domestic Product/Capita (U.S. Dollars) \\
\hline Qatar & 129,700 \\
\hline Kuwait & 71,300 \\
\hline United Arab Emirates & 67,700 \\
\hline Saudi Arabia & 54,100 \\
\hline Bahrain & 50,300 \\
\hline
\end{tabular}




\begin{tabular}{|c|c|}
\hline Country/Entity & Gross Domestic Product/Capita (U.S. Dollars) \\
\hline Oman & 43,700 \\
\hline Israel & 34,800 \\
\hline EU average & 33,700 \\
\hline Turkey & 21,100 \\
\hline Lebanon & 18,500 \\
\hline Iran & 18,100 \\
\hline Egypt & 12,100 \\
\hline Jordan & 11,100 \\
\hline Iraq & 16,500 \\
\hline Syria & 2,900 \\
\hline Yemen & 2,500 \\
\hline
\end{tabular}

Source: World Bank. 2018a. "GDP per capita.". Accessed October 25, 2018. https://data.worldbank.org/indicator/NY.GDP.PCAP.CD?locations=PL-GR-PT-DEEU and World Atlas. 2017. "The Richest And Poorest Economies In The Middle East." Accessed October 25, 2018. https://www.worldatlas.com/articles/the-richest-andpoorest-economies-in-the-middle-east.html.

The data in the table above shows that the Middle East region is comprised of very rich states, where GDP/capita is higher than the EU average (Qatar, Kuwait, United Arab Emirates, Saudi Arabia or Bahrain), but also of very poor states (e.g. Iraq, Syria or Yemen) that represent important sources of migration toward the territory of the European Union.

\subsection{Migration statistics}

The intensification of armed conflicts in the Middle East and the increasing economic disparities between the Middle East countries and the Member States of the European Union have indirectly determined an increase of the migratory flux between the two regions in the past three decades. 
Table no. 3. Number of migrants from the Middle East to the European Union between 1991 and 2015

\begin{tabular}{|c|c|}
\hline Period & Number of migrants \\
\hline $\mathbf{1 9 9 1 - 1 9 9 5}$ & 657,126 \\
\hline $\mathbf{1 9 9 6 - 2 0 0 0}$ & 725,824 \\
\hline $\mathbf{2 0 0 1 - 2 0 0 5}$ & 438,585 \\
\hline $\mathbf{2 0 0 6 - 2 0 1 0}$ & 498,358 \\
\hline $\mathbf{2 0 1 1 - 2 0 1 5}$ & 926,852 \\
\hline
\end{tabular}

Source: Lucassen, Leo. 2018. "Peeling an onion: the refugee crisis from a historical perspective." Ethnic and Racial Studies 41 (3): 387.

The Middle East not only represents a region that provides today more immigrants to the European Union than three decades ago, but also the main supplier of immigrants in comparison with all the other regions of the world.

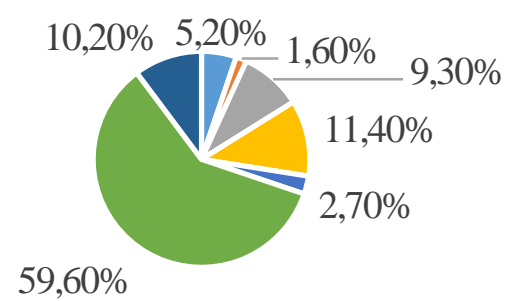
- Horn of Africa
- Northern Africa
- Subsaharian Africa
- Europe
- Rest of Asia
- The Middle East
- Rest of the world

Figure 7. The origin of asylum seekers in the European Union between July 2014 and June 2016

Source: Lucassen, Leo. 2018. "Peeling an onion: the refugee crisis from a historical perspective." Ethnic and Racial Studies 41 (3): 389. 
The data in the figure above reflects the true dimensions of the migration flux from the Middle East to the European Union, a phenomenon determined by long armed conflicts, continuous social tensions and major economic disparities between the countries of this region and the Member States of the EU. All these factors have led to the current situation where more than $50 \%$ of the total asylum seekers in the EU originate in one of the states that can be placed from a geographic or from a geopolitical perspective in the Middle East region.

\section{CONCLUSIONS}

The analysis of the migration flux from the Middle East to the European Union has shown that this phenomenon is determined by a complexity of determinant factors like the demographic structure of the countries in the Arabic Peninsula and Northern Africa, the political instability in most of the states that are part of this region, the unprecedented development of radical movements in the past decades or the long history of cultural, political and economic relations between Europe, on one hand, and the Middle East, on the other hand.

Although each of these factors contribute to the general flux of migration from the Middle East to the European Union, two other determinants have been identified as being the main causes that support the migratory phenomenon that connects these regions: the numerous armed conflicts in the Middle East and the important economic disparities that differentiate between the developed economies of the EU and the developing economies of many of the countries in the Middle East.

These two causes can explain not only the migration flux from the Middle East to the European Union in general, but also the recent migratory spurt from Syria to the EU, if we take into consideration that in this country a major civil war has been developing in the past years and that the indicators that characterize the Syrian economy are far worse than the same indicators that characterize the EU economy.

These results show that measures need to be taken at the EU level if the Member States want to prevent future migration crises originating from the Middle East. 
These measures have to address in the first place the two main causes of immigration (the frequent armed conflicts and the economic underdevelopment) and have to be based on active policies aimed at fostering peace and economic growth in the Middle East region.

\section{REFERENCES}

- $\quad$ Adamczyk, Artur. 2018. "Prospects for Extending the European Union to the Countries of the Western Balkans." Studia Europejskie-European Studies Affairs 88 (4): 125-148.

- Binder, Leonard. 1958. "The Middle East as a subordinate international system." World Politics 10 (3): 408-429.

- Black, Ian. 2014. "A guide to Middle East politics in 2014.". Accessed October 22, 2018. https://www.theguardian.com/world/2014/aug/04/sp-middle-east-politics-2014-egypt-syria-palestine-iraq-gaza.

- Daștan, Ahmet. 2019. "Caracteristicile socio-culturale ale migrației din Orientul Apropiat în Uniunea Europeană: Studiu de caz comunitatea Hizmet". PhD diss., National University of Political Studies and Public Administration.

- $\quad$ European Commisssion. 2015. "Legal Migration in the EU. From Stop-Gap Solutions to a Future-Proof Policy." EPSC Strategic Notes, no. 2. Accessed October 15, 2018. https://ec.europa.eu/epsc/ sites/epsc/files/strategic_note_issue_2.pdf.

- $\quad$ Eurostat. 2017. "Immigration by citizenship." Accessed October 16, 2018. https://ec.europa.eu/eurostat/statisticsexplained/index.php?title=File:Immigration_by_citizenship,_2016.png

- Faucett, Louise. 2016. "Introduction: The Middle East and International Relations." In International Relations of the Middle East, edited by Louise Faucett, $4^{\text {th }}$ edition. Oxford: Oxford University Press.

- Gerner, Deborah. 2018. One land, two peoples: The conflict over Palestine. Abingdon: Routlege. 
- Hashas, Mohammed. 2018. The Idea of European Islam: Religion, Ethics, Politics and Perpetual Modernity. Abingdon: Routlege.

- Lazăr, Marsius. 2005. "Strategiile Uniunii Europene în Orientul Mijlociu." GeoPolitica 3 (13): 141-149.

- $\quad$ Lucassen, Leo. 2018. "Peeling an onion: the refugee crisis from a historical perspective." Ethnic and Racial Studies 41 (3): 383-410.

- Nisan, Mordechai. 2012. Minorities in the Middle East: a history of struggle and self-expression. Jefferson: McFarland.

- Noble, Paul. 1991. "The Arab system: pressures, constraints, and opportunities." The foreign policies of Arab States: The challenge of change: 49102.

- O'Callaghan, Joseph. 2013. Reconquest and crusade in medieval Spain. Philadelphia: University of Pennsylvania Press.

- $\quad$ Owen, Roger. 2013. State, power and politics in the making of the modern Middle East. Abingdon:Routlege.

- $\quad$ Romero, Carolina. 2019. "Analyzing the United States' Limited Response to the Syrian Refugee Crisis." Political Analysis 20 (1): 3.

- Schengen Visa Info. 2019. "The European Union and countries in the EU." Accessed November 12, 2019. https://www. schengenvisainfo.com/eucountries/.

- Schimmel, Annemarie. 1992. Islam: an introduction. Albany: SUNY Press.

- $\quad$ Totten, Samuel, Paul Bartrop and Steven Jacobs. 2008. Dictionary of Genocide. Westport: Greenwood Publishing Group.

- Trading Economics. 2018. "Turkey GDP.". Accessed October 19, 2018. https://tradingeconomics.com/turkey/gdp.

- United Nations. 2019. "Global Compact for Migration." Accessed November $\quad 2019.2$ https://www.ohchr.org/ EN/Issues/Migration/Pages/GlobalCompactforMigration.aspx.

- U.S. Department of State. 2017. "Foreign Terrorist Organizations.". Accessed October 17, 2018. https://www.state.gov/j/ ct/rls/other/des/123085.htm. 
- Waterbury, John. 2014. The Egypt of Nasser and Saddat: the political economy of two regimes, New Jersey: Princeton University Press.

- World Atlas. 2017. "The Richest And Poorest Economies In The Middle East." Accessed October 25, 2018. https://www.worldatlas.com/articles/the-richest-and-poorest-economiesin-the-middle-east.html.

- World Bank. 2018. "Global Economic Prospects 2018: Middle East \& North Africa.". Accessed October 2018. https://www.worldbank.org/en/region/mena/publication/gep-2018.

- World Bank. 2018a. "GDP per capita.". Accessed October 25, 2018. https://data.worldbank.org/indicator/ NY.GDP.PCAP.CD?locations=PLGR-PT-DE-EU.

- World Population Review. 2018. "2018 World Population by Country." Accessed October 17, 2018. http:/ / world population review.com/.

- Yousef, Tarik. 2004. "Development, growth and policy reform in the Middle East and North Africa since 1950." Journal of Economic Perspectives 18 (3): 91-115. 